Website: http://journal.hibiscuspublisher.com/index.php/AJPB/index
PUBLISHER

\title{
Characterization of Morganella sp. for its Paraquat Degradation Potential
}

\author{
Haruna, S.D. ${ }^{1}$, Sufyan, A.J. ${ }^{1}$ Ibrahim, S. ${ }^{1,2}$, Babandi, A. ${ }^{1}$, Shehu, D. ${ }^{1}$, Ya'u, M. ${ }^{1}$, Babagana, K. ${ }^{3}$, Sani, I. ${ }^{1}$ and H. \\ M. Yakasai ${ }^{1 *}$
}

${ }^{1}$ Department of Biochemistry, Faculty of Basic Medical Sciences, College of Health Science, Bayero University, Kano, P. M. B 3011, Nigeria.

${ }^{2}$ Centre for Biotechnology Research, Bayero University Kano P. M. B 3011, Nigeria.

${ }^{3}$ Kebbi State University of Science and Technology, Aliero, P. M. B 1144, Birnin Kebbi, Nigeria.

\author{
*Corresponding author: \\ Dr. H.M. Yakasai, \\ Department of Biochemistry, \\ Faculty of Basic Medical Sciences, \\ College of Health Science, \\ Bayero University, Kano, \\ P. M. B 3011, \\ Nigeria.
}

Email: hmyakasai.bch@buk.edu.ng

\section{HISTORY \\ Received: $5^{\text {th }}$ Oct 2021 \\ Received in revised form: $25^{\text {th }}$ Nov 2021 Accepted: 14 th $\operatorname{Dec} 2021$}

\section{KEYWORDS}

Herbicide

Toxic

Bacteria

Growth

Culture collection

\begin{abstract}
One of the beneficial roles of the microbial population is their ability to convert toxic herbicides to lesser toxic compounds such as water and carbon (IV) oxide. Paraquat which is an acutely toxic herbicide is used on farmlands and has been found to affect human health. This study was aimed at characterizing bacteria with the potential to degrade paraquat. Previously isolated bacteria from culture collection labelled A-F were screened for their potential to degrade and utilized paraquat as the sole carbon source in Bushnell Hass agar media. Of the six isolates, isolate E (Morganella sp.) was observed to have the highest growth and tolerance to paraquat after $72 \mathrm{~h}$ of incubation at $37^{\circ} \mathrm{C}$. Characterization study revealed that Morganella sp. can utilize and grow with optimum conditions of $\mathrm{pH} 6.5$, the temperature of $30^{\circ} \mathrm{C}$ and can tolerate up to $400 \mathrm{mg} / \mathrm{L}$ paraquat concentration with an increase in growth as inoculum size increases. Thus, these findings showed that Morganella sp. can degrade toxic paraquat to a less toxic form and therefore can be a good isolate for the future bioremediation process of the pollutant.
\end{abstract}

\section{INTRODUCTION}

The use of chemical compounds in modern agricultural systems have become common, one group of such chemicals is a herbicide, used to control weed, protect crops and increase agricultural yield [1]. Paraquat is a non-selective rapid-acting herbicide that destroys plants on contact [1]. Paraquat toxicity has been reported by several researchers. In vivo toxicity study of paraquat showed the herbicide can cause lipid peroxidation of cell membranes, therefore, damaging the cells in mice [2]. Study of lungs tissue of rats after a single oral dose of paraquat indicated pulmonary oedema, swelling of the epithelium, an increase in collagen, and an effect on the ribosomes of the membranous pneumocytes [3]. It also produces degenerative lesions in the lung after systemic administration to man and animals [4]. Moreover, the use of the herbicide paraquat $\left(1,1^{\prime}\right.$-dimethyl-4,4bipyridylium dichloride; PQ) has been strongly challenged due to its critical acute toxicity, putative neurotoxicity after long-term exposure and lack of antidotes to counteract its effects [5]. Paraquat is classified as a Category II oral toxicity and a Category III cutaneous toxicity. ingesting pure paraquat may result in severe inflammation and even death in humans, as well as in the development of the life-threatening condition known as acute respiratory distress syndrome (ARDS). According to several sources, the death rate ranges from 60 to 90 per cent $[6,7]$ Ingestion of paraquat is often the cause of accidental death or suicide. Paraquat poisoning, for example, is responsible for more than 5,000 annual fatalities in China [8]. Due to the lack of a particular antidote for paraquat (PQ), suicides in India are a major source of illness and death [9]. Damage to organs like the pulmonary alveolar epithelium results from free radicals generated during the metabolism of phenylephrine (PQ). Acute multiorgan failure and mortality occur during the first two days after PQ consumption of more than $40 \mathrm{mg} / \mathrm{kg}$, but PQ consumption less than $20 \mathrm{mg} / \mathrm{kg}$ is associated with moderate symptoms and the majority of patients survive.

Severe mucosal damage and multiorgan failure are the results of paraquat exposure at doses between 20 and $40 \mathrm{mg} / \mathrm{kg}$. Lung fibrosis claims the lives of those who are lucky enough to make it through the first week. It is only the polyamines essential for the cellular activity that is stored in the pulmonary alveolar 
cells. Because of its structural resemblance to polyamines, PQ builds up in these cells and causes prolonged harm to the lungs. Despite the lack of a particular antidote, most patients are given steroids/cyclophosphamide/antioxidants to counteract the effects of free radicals [10-12]. The U.S. Environmental Protection Agency (EPA) found no evidence of reproductive/fertility harm from long-term exposure to paraquat, even though it is prone to causing lung and eye injuries. Pumping the stomach to remove as much paraquat as possible is the first step in the traditional therapy for paraquat poisoning. It's possible that using activated charcoal or Fuller's earth can boost results, but it depends on when you use it. Additionally, hemodialysis, hemofiltration, haemoperfusion, and antioxidant treatment may also be recommended. Anti-inflammatory drugs including glucocorticoids and cyclophosphamide have been proposed by some, although the data supporting their use in combination with normal treatment is inconclusive. Even if glucocorticoid is added to normal therapy, it isn't known whether it has undesired side effects including an increased risk of infection. High quantities of oxygen should not be provided until $\mathrm{SpO} 2$ is less than 92 per cent. Death may occur up to 30 days after ingestion [10-12].

PAs are an acute inhalation hazard, paraquat is rated as Toxicity Category I (the most hazardous) by the EPA. The Environmental Protection Agency (EPA) ruled those agricultural operations $(400-800 \mathrm{~m})$ are not in the range of particles that may be inhaled. The eye and skin may also be irritated by paraquat. The biggest danger of unintentional paraquat poisoning occurs during the mixing and loading of paraquat for usage. Poisoning has a significant impact on the lungs. In a few days to weeks, the liver, heart, lungs, and kidneys may all fail, which can lead to death within 30 days after intake.

The chances of surviving a substantial exposure are slim. Lung damage, renal failure, heart failure, and oesophageal strictures are all possible outcomes of prolonged exposure. Paraquat's harmful effects on people are still a mystery. When highly reactive oxygen species and nitrite species are generated, oxidative stress occurs, which leads to acute inflammation. Damage to the organs might be caused by inducing cell death, inducing the death of mitochondria, or inducing oxidative stress. For example, it is known that paraquat is concentrated in the alveolar epithelium of the lung. Small amounts, even if taken from the stomach or spat out, may still lead to asphyxiation from fibrous tissue in the lungs, even if they are eliminated from the body [12-15].

Bioremediation techniques involve the use of microorganisms, these strategies can eliminate or reduce xenobiotics in the environment [16-18]. The technique also displayed great potential regarding cost compared to other methods $[19,20]$. Nevertheless, microbial degradation has been proven to be the safest method of ridding the environment of its pollutants [21-23]. The search for multi-degrader microbe is a continuous process, as no single isolate can tolerate or detoxify all toxic chemicals. This work will thus, screen previously isolated bacteria for their potential to degrade paraquat as the sole carbon source.

\section{MATERIALS AND METHODS}

\section{Chemicals and equipment}

Paraquat with high purity was purchased from local distributors in the Kano market, Nigeria. Bushnell Hass media containing $\left(\mathrm{gL}^{-1}\right): \mathrm{CaCl}_{2}, \mathrm{FeCl}_{3}, \mathrm{MgSO}_{4}, \mathrm{KH}_{2} \mathrm{PO}_{4}, \mathrm{~K}_{2} \mathrm{HPO}_{4}, \mathrm{NH}_{4} \mathrm{NO}_{3}$, was used to study paraquat degradation by bacterial isolates. The nutrient broth was used for the growth of the bacterial culture.

\section{Media and Media Preparation} Nutrient Agar

In a $250 \mathrm{ml}$ conical flask, $3.4 \mathrm{~g}$ of nutrient agar was added to 120 $\mathrm{ml}$ of distilled water and autoclaved at $121{ }^{\circ} \mathrm{C}$ for 45 minutes. The medium was used to determine the viability of isolates

\section{Mineral salt medium}

Liquid media was prepared by adding $(\mathrm{g} / \mathrm{L}) \mathrm{KH}_{2} \mathrm{PO}_{4}, \mathrm{~K}_{2} \mathrm{HPO}_{4}$, $\mathrm{MgSO}_{4}, \mathrm{CaCl}_{2}, \mathrm{FeCl}_{3}, \mathrm{NH}_{4} \mathrm{NO}_{3}$ to $700 \mathrm{ml}$ of distilled water in a $1000 \mathrm{ml}$ conical flask. A measured volume of the medium was then taken and transferred each into a conical flask, the flask containing the medium was then autoclaved at $121{ }^{\circ} \mathrm{C}$ for 45 minutes. $100 \mathrm{mg}$ (unless otherwise stated) concentration of paraquat was used in the different flasks prepared in triplets which were used for degradation study. Agar was added to solidify the media.

\section{Screening for Paraquat-Degrading Isolates}

Screening of isolates was carried out in a petri dish. In each plate, $20 \mathrm{ml}$ of prepared solid media was added under a lamina flow and allowed to solidify. To all the Petri dish, bacterial isolates, labelled (A-F) were streaked using a wire loop and incubated for three days. Screening of maximum growth was done macroscopically.

\section{Characterization of Paraquat-Degradation}

\section{Effect of Paraquat Concentration}

The effect of paraquat concentration media was tested by adding Morganella sp. inoculum of $100 \mu 1$ concentration into the liquid media containing different paraquat concentrations $(\mathrm{mg} / \mathrm{L}) ; 50$, $100,200,400,600$ and 800 concentrations were added in triplicate and incubated. Optical densities were measured at $24 \mathrm{~h}$ intervals using a spectrophotometer at a wavelength of $600 \mathrm{~nm}$ to observe the growth rate of the isolate. Control bottles were prepared without the inoculum and kept under the same condition as the inoculated test bottles.

\section{Effect of $\mathbf{p H}$}

The effect of $\mathrm{pH}$ of the media was tested by adding Morganella sp. inoculum of $100 \mu \mathrm{l}$ concentration into the liquid media of varying $\mathrm{pH}(5.5,6.0,6.5,7.0,7.5,8.0)$ and incubated. The $\mathrm{pH}$ was adjusted using $\mathrm{NaOH}$ and $\mathrm{HCl}$ prior to the sterilization. Optical densities were measured at $24 \mathrm{~h}$ intervals using a spectrophotometer at a wavelength of $600 \mathrm{~nm}$ to observe the growth rate of the isolate. Control bottles were prepared without the inoculum and kept under the same condition as the inoculated test bottles.

\section{Effect of Inoculum Size}

The effect of inoculum size was tested by inoculating different volumes $(100,200,400,600,800$ and $1000 \mu \mathrm{l})$ of Morganella sp. into the liquid media and incubated for $120 \mathrm{mhrs}$. Optical densities were measured at $24 \mathrm{~h}$ intervals using a spectrophotometer at a wavelength of $600 \mathrm{~nm}$ to observe the growth rate of the isolate. Control bottles were prepared without the inoculum and kept under the same condition as the inoculated test bottles.

\section{Effect of Temperature}

The effect of temperature was tested by inoculating Morganella sp. Into $100 \mathrm{ml}$ of the liquid media in $250 \mathrm{ml}$ bottles and incubated for $120 \mathrm{~h}$ at different temperatures of $25,30,37$, and $40{ }^{\circ} \mathrm{C}$ respectively. Optical density was measured at $24 \mathrm{~h}$ intervals using a spectrophotometer at a wavelength of $600 \mathrm{~nm}$ to observe the growth rate of the isolate. Control culture were 
prepared without the inoculums and kept under the same conditions as the inoculated test flasks.

\section{Effect of Incubation Time}

Prepared liquid media (Bushnell Hass) supplemented with $0.1 \mathrm{~g} /$ of Paraquat was inoculated with $100 \mu \mathrm{L}$ of Morganella sp. in triplicate. Also controls, without inoculation of Morganella sp. were kept under similar conditions. Optical densities (OD) were measured at regular intervals of time $24 \mathrm{~h}$ up to $120 \mathrm{~h}$ using a spectrophotometer at $600(\mathrm{~nm})$ to determine the optimum growth temperature for paraquat biodegradation.

\section{RESULTS}

\section{Screening of Isolates for Paraquat Biodegradation}

A total of six (6) molybdenum-reducing bacteria was previously isolated from agricultural soils in Kano state were screened for their potentials to degrade Paraquat and utilize it as a sole carbon source. The isolate E (Morganella $\mathrm{sp}$.) was observed to tolerate and grow best on Bushnell Hass media containing Paraquat as a sole carbon source following $48 \mathrm{~h}$ of incubation at $37^{\circ} \mathrm{C}$, thus was chosen for further analysis.

\section{Characterization of paraquat-degradation by Morganella sp.}

\section{Effect of concentration on paraquat biodegradation}

The effect of various paraquat concentrations on its degradation was determined between $50-800 \mathrm{mg} / \mathrm{L}$. Paraquat concentration was observed to be optimum at $400 \mathrm{mg} / \mathrm{L}$ for this isolate with a decline in growth on increasing the concentration to $800 \mathrm{mg} / \mathrm{L}$ (Fig. 1).

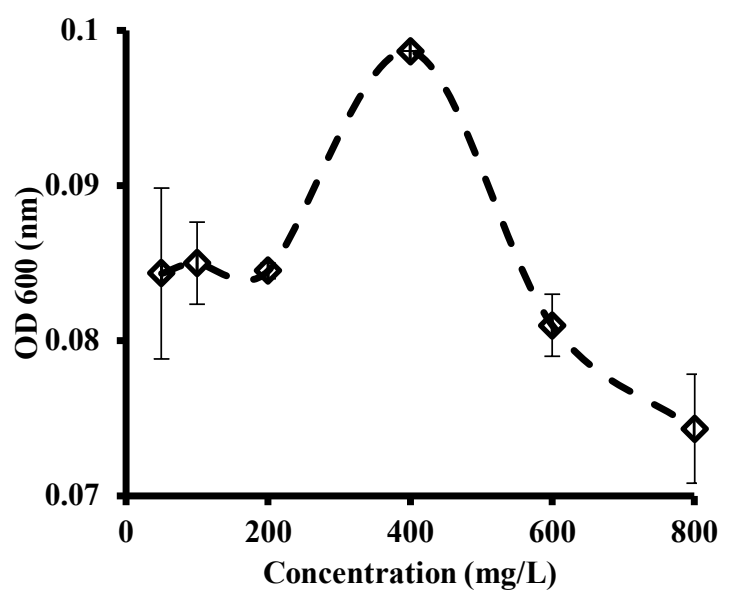

Fig. 1. Effect of concentrations of paraquat (carbon source) on its degradation by Morganella sp. after $96 \mathrm{hrs}$. of incubation at $37^{\circ} \mathrm{C}$. Data represent mean \pm standard deviation of triplicate determination.

\section{Effect of pH on paraquat biodegradations}

The effect of initial $\mathrm{pH}$ on paraquat degradation was tested at different $\mathrm{pH}$ range between 5.5 -8.0. The result obtained showed that the growth of the bacterium was optimum at a $\mathrm{pH}$ of 6.5 after $48 \mathrm{hrs}$ of incubation (Fig. 2).

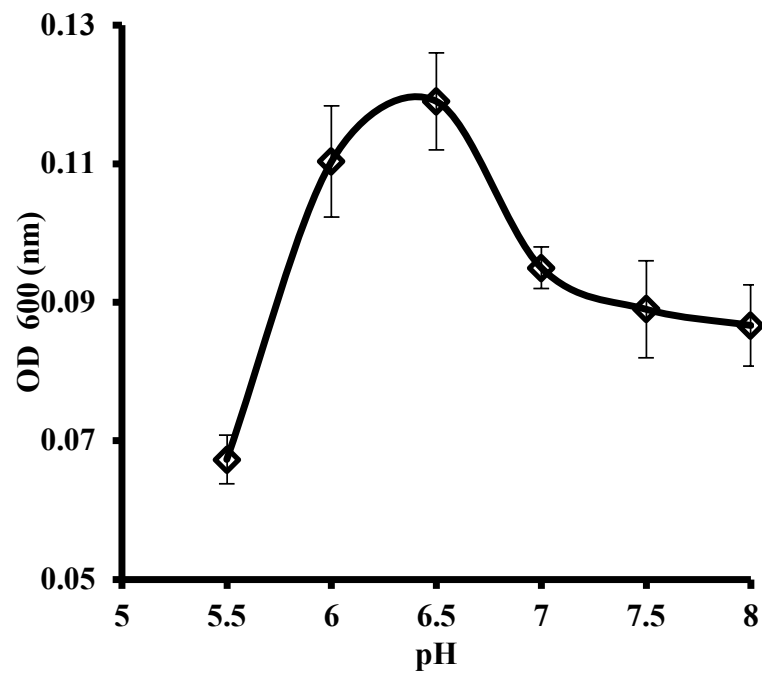

Fig. 2. Effect of initial $\mathrm{pH}$ on paraquat degradation by Morganella $\mathrm{sp}$ Data represent mean \pm standard deviation of triplicate determination.

\section{Effect of inoculum size on paraquat biodegradation}

The inoculum sizes between 100 to $1000 \mu \mathrm{L}$ were used to determine the effect of inoculum size. The result obtained shows that the growth of this isolate on paraquat increases with an increase in the inoculum (Fig. 3).

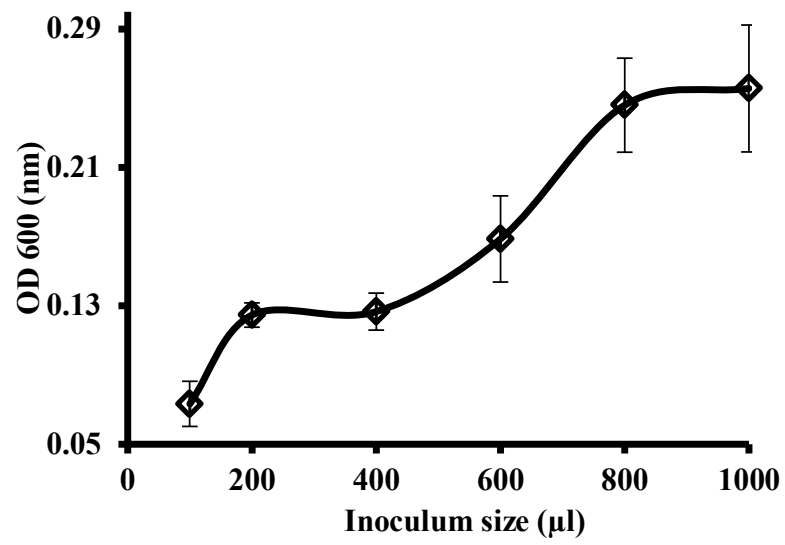

Fig. 3. Effect of various Inoculum sizes on paraquat degradation by Morganella sp. after $96 \mathrm{hrs}$ of incubation at $37^{\circ} \mathrm{C}$. Data represents mean \pm standard deviation of triplicate determination.

\section{Effect of temperature on paraquat biodegradation}

The effect of temperature on the growth and paraquat-degrading potentials of Morganella sp. was tested within a temperature range between $25-40{ }^{\circ} \mathrm{C}$. It was observed that $30{ }^{\circ} \mathrm{C}$ to be the optimum temperature after $72 \mathrm{~h}$ (Fig. 4). 




Fig. 4. Effect of temperature on optimum paraquat degradation by Morganella sp. after 48 Hrs. Data represent mean \pm standard deviation of triplicate determination.

\section{Effect of incubation time on paraquat degradation}

The result of the effect of incubation time shows that Morganella $\mathrm{sp}$. was found to grow exponentially from 0 to $96 \mathrm{~h}$ at which the maximum growth is observed. Growth declined from that time signifies its death phase.

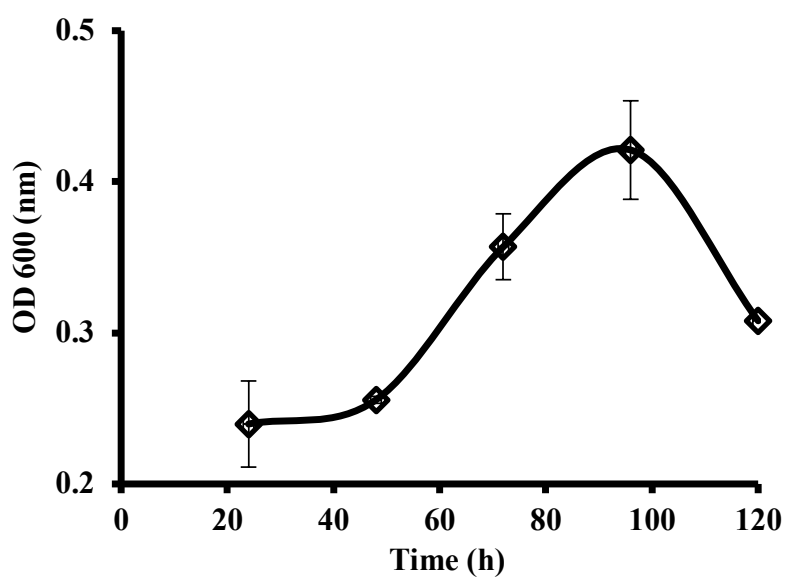

Fig. 5. Effect of Various incubation times on Paraquat degradation by Morganella sp. Data represent: Mean \pm Standard Deviation of triplicate determination.

\section{DISCUSSION}

Bioremediation exploits the ability of microorganisms to degrade and detoxify organic contaminants. It has been an efficient, economic, versatile and environmentally sound biological treatment method [24]. The herbicide paraquat is comparatively safe for soil microorganisms and plant roots, but its long-term exposure results in harmful biomagnifications in humans and mammals [25]. Extensive paraquat applications lead to widespread residues in the soil surface and aquatic environments that ultimately enter the food chain [26].
Effect of concentration between 50 to $800 \mathrm{mg} / \mathrm{L}$ tested in this study showed that the bacterium can grow and tolerate up to $400 \mathrm{mg} / \mathrm{L}$ concentration, a concentration that contradicts most if not all of the reported bacteria with paraquat degradation potentials tolerable concentration. On the other hand, a test set to determine the effect of $\mathrm{pH}$ on the degradation of paraquat by Morganella $\mathrm{sp}$. showed that the bacteria can grow best at $\mathrm{pH}$ of 6.5 with an optimum temperature of $30^{\circ} \mathrm{C}$. Similar optimum temperatures and slightly higher $\mathrm{pH}$ of 7.0 have been reported on paraquat degradation by Bacillus aryabhattai [27].

Finally, the test to determine the effect of inoculum sizes showed an increase in growth as the inoculums size increases, this can be explained by the fact that bacterial growth curve rate increases exponentially with larger healthy inoculum.

\section{CONCLUSION}

The potential of previously isolated Morganella sp. to tolerate, degrade and utilize paraquat as the sole carbon source was exploited in this study. The bacterium degrades the herbicide best at optimum $\mathrm{pH}$ of 6.5 , temperature $30{ }^{\circ} \mathrm{C}$, concentration of 400 $\mathrm{mg} / \mathrm{L}$ and $1000 \mu \mathrm{L}$ inoculum after $96 \mathrm{hrs}$ of incubation. This bacterium can be utilized for future biodegradation of this environmental pollutant.

\section{REFERENCES}

1. Teerakun M. Optimization of paraquat degradation with microbia consortium from contaminated soil using statistic method. Int $\mathrm{J}$ GEOMATE. 2020 Apr 1;18(68):73-9.

2. Bus JS, Aust SD, Gibsont JE. Paraquat Toxicity: Proposed Mechanism of Action Involving Lipid Peroxidation. 1976;16(August):139-46.

3. Kimbrough RD, Gaines TB. Toxicity of Paraquat to Rats and Its Effect. 1970;690:679-90.

4. Bus JS, Gibson JE. Paraquat : Model for Oxidant-Initiated Toxicity. 1984;55:37-46.

5. Baltazar T, Dinis-oliveira RJ, Duarte JA. Paraquat research : do recent advances in limiting its toxicity make its use safer? 2012;2012-3.

6. Pratt I, Keeling P, Smith LL. The effect of high concentrations of oxygen on paraquat and diquat toxicity in rats. Arch Toxicol Suppl Arch Toxikol Suppl. 1980;4:415-8.

7. Li LR, Chaudhary B, You C, Dennis JA, Wakeford H Glucocorticoid with cyclophosphamide for oral paraquat poisoning Cochrane Database Syst Rev. 2021 Jun 30;6:CD008084.

8. Yin Y, Guo X, Zhang SL, Sun CY. Analysis of paraquat intoxication epidemic (2002-2011) within China. Biomed Environ Sci BES. 2013 Jun;26(6):509-12.

9. Agarwal R, Srinivas R, Aggarwal AN, Gupta D. Experience with paraquat poisoning in a respiratory intensive care unit in North India. Singapore Med J. 2006 Dec;47(12):1033-7.

10. Sun B, Chen Y-G. Advances in the mechanism of paraquat-induced pulmonary injury. Eur Rev Med Pharmacol Sci. 2016 Apr;20(8):1597-602.

11. Isha IT, Alam ZHMN, Shaha BK, Bari MS, Bari MZJ, Chowdhury FR. Paraquat induced acute kidney injury and lung fibrosis: a case report from Bangladesh. BMC Res Notes. 2018 May 30;11(1):344.

12. Tao X, Yu G, Guo W, Kan B, Song L, Li H, et al. Esophagitis dissecans superficialis associated with acute transoral paraquat poisoning: Clinical study of 15 cases. Sci Prog. 2021 Apr 1;104(2):00368504211019647.

13. Janeela MA, Oommen A, Misra AK, Ramya I. Paraquat poisoning Case report of a survivor. J Fam Med Prim Care. 2017;6(3):672-3.

14. Banagozar Mohammadi A, Nahandi M, Mohammadian S. The Successful Treatment of High Lethal Dose Paraquat Poisoning With Hemoperfusion. Int J Med Toxicol Forensic Med. 2020 Sep 29;10:26726.

15. Montoya-Giraldo MA, Díaz LF, Gómez UE, Quintero J, Zuluaga AF. Use of low-molecular-weight heparin in severe paraquat 
poisoning: a case report. J Med Case Reports. 2020 Dec $8 ; 14(1): 240$.

16. Barh B AG, Kumar Singh B NG. Enhanced bioremediation techniques for agricultural soils. 2015;3(7):166-73.

17. Kumar A, Joshi V, Dhewa T, Bisht B. Review on bioremediation of polluted environment: A management tool. Int J Environ Sci. 2011;1(6):1079.

18. Artin H. Principles of bioremediation processes. Vol. 661, Trends in Bioremediation and Phytoremediation. 2010. 23-54 p.

19. Kim S, Krajmalnik-Brown R, Kim JO, Chung J. Remediation of petroleum hydrocarbon-contaminated sites by DNA diagnosisbased bioslurping technology. Sci Total Environ. 2014 Nov 1;497498:250-9.

20. Azubuike CC, Chikere CB, Okpokwasili GC. Bioremediation techniques-classification based on site of application: principles, advantages, limitations and prospects. World J Microbiol Biotechnol. 2016;32(11).

21. Andy IE, Bassey IU. Biodegradation of paraquat. 2017;(March 2015).

22. Asogwa EU, Dongo LN. Problems associated with pesticide usage and application in Nigerian cocoa production: A review. 2009;4(8):675-83.

23. Kang DG, Choi SS, Cha HJ. Enhanced Biodegradation of Toxic Organophosphate Compounds Using Recombinant Escherichia coli with Sec Pathway-Driven Periplasmic Secretion of Organophosphorus Hydrolase. 2006;406-10.

24. Feidieker D, Kampfer P, Dott W. Microbiological and chemical evaluation of a site contaminated with chlorinated aromatic compounds and hexachlorocyclohexanes. 1994;15:265-78.

25. Frimpong JO, Ofori ESK, Yeboah S, Marri D, Offei BK, Apaatah $\mathrm{F}$, et al. Evaluating the impact of synthetic herbicides on soil dwelling macrobes and the physical state of soil in an agroecosystem. Ecotoxicol Environ Saf. 2018;156:205-15.

26. Pateiro-Moure M, Nóvoa-Muñoz JC, Arias-Estévez M, LópezPeriago E, Martínez-Carballo E, Simal-Gándara J. Quaternary herbicides retention by the amendment of acid soils with a bentonite-based waste from wineries. J Hazard Mater. 2009;164(2):769-75.

27. Inthama P, Pumas P, Pekkoh J, Pathom-aree W. Plant Growth and Drought Tolerance-Promoting Bacterium for Bioremediation of Paraquat Pesticide Residues in Agriculture Soils. 2021;12(March):1-14. 